Cita: Buendía-Romero, Á., García-Conesa, S., Pallarés, J.G. \& Courel-Ibáñez, J. (2020). Effects of a 4-week multicomponent exercise program (Vivifrail) on physical frailty and functional disability in older adults living in nursing homes. Cuadernos de Psicología del Deporte, 20(3), 75-81

\title{
Effects of a 4-week multicomponent exercise program (Vivifrail) on physical frailty and functional disability in older adults living in nursing homes
}

\section{Efectos de 4 semanas del programa de entrenamiento multicomponente (Vivifrail) en la fragilidad y capacidad funcional en adultos mayores que viven en una residencia de ancianos}

\section{Efeitos de 4 semanas do programa de treinamento multicomponente (Vivifrail) na fragilidade e capacidade funcional de idosos que vivem em residências}

\author{
Buendía-Romero, Á.1, García-Conesa, S.1, Pallarés, J.G.1 \& Courel-Ibáñez, J.1 \\ ${ }_{1}$ Faculty of Sport Sciences, Human Performance and Sports Science Laboratory, \\ University of Murcia, Murcia, Spain
}

\begin{abstract}
This study determined the effects of a 4-week individualized multicomponent exercise program (Vivifrail) on physical frailty and functional disability in older adults living in nursing homes. Fourteen institutionalized older adults (aged $81.7 \pm 9.7$ years) volunteered to completed 4 weeks of the individualized Vivifrail exercise program (5 days a week) according to their initial level: A, disability; B, frailty; C, pre-frailty and D, robust. Training sessions were directed by strength and conditioning trainers. Eleven participants completed the pre and post evaluations with very high levels of attendance (96\% of the training sessions). Functional capacity (SPPB scores) significantly improved in all the participants $(+48.2 \%, p<0.001)$ and tests: sit-to-stand $(24.1 \%$ faster, $p=0.003)$, gait speed $4 \mathrm{~m}$ (9.8\% faster, $p=0.033)$ and $6 \mathrm{~m}(7.2 \%$ faster, $p=0.017)$ and $\mathrm{Up}$ and Go (11.2\% faster, $p=0.004)$. Disability and sarcopenia decreased significantly (SARC-F, $p=0.026$; Lawton index, $p=0.013$ ). People with initial levels of disability (A), frailty (B) and pre-fragility (C) shown the greatest improvements. Six of the nine participants who started with physical frailty or pre-frailty status $(66.7 \%)$ reversed this condition after the intervention. In addition, $33 \%$ of participants with disability, who were unable to perform the functional tests (sit-stand and walk), became able to complete them after the intervention. These important benefits found in such a shorter period of time ( 4 weeks) could be related to three key elements: individualization of the program, daily frequency and face-to-face coaching motivation by physical conditioning professionals.
\end{abstract}

Keywords: Elderly, falls, long-term care facilities, primary care. 


\section{Buendía-Romero, Á., García-Conesa, S., Pallarés, J.G. \& Courel-Ibáñez, J.}

\section{RESUMEN}

En este estudio se determinaron los efectos de un programa de ejercicio multicomponente individualizado de 4 semanas (Vivifrail) sobre la fragilidad física y la discapacidad funcional en adultos mayores que viven en hogares de ancianos. Catorce personas institucionalizadas (edad 81,7 \pm 9,7 años) se ofrecieron voluntarios para completar 4 semanas del programa de ejercicio individualizado Vivifrail (5 días a la semana) de acuerdo con su nivel inicial: A, discapacidad; B, fragilidad; C, pre-fragilidad y D, robusto. Los entrenamientos fueron dirigidos por educadores físico-deportivos titulados. Once participantes completaron las 4 semanas con niveles muy altos de asistencia (96\%). La capacidad funcional (puntuación del SPPB) mejoró en todos los participantes $(+48.2 \%, p<0.001)$ y tests: levantarse de la silla $(24.1 \%, p=0.003)$, velocidad de marcha $4 \mathrm{~m}(9.8 \%, p=0.033)$ y $6 \mathrm{~m}(7.2 \%, \mathrm{p}=0.017)$ y test Up and Go (11.2\%, $p=0.004)$. La discapacidad y sarcopenia disminuyeron significativamente (SARC-F, $p=0.026$; índice de Lawton, $p=0.013$ ). Las personas que empezaron con niveles de discapacidad (A), fragilidad (B) y prefragilidad (C) mostraron mejores resultados. Seis de los nueve participantes que comenzaron con fragilidad física o pre-fragilidad (66.7\%) revirtieron esta condición tras la intervención. Además, el 33\% de los participantes que fueron incapaces de realizar las pruebas funcionales (sentarse, levantase y caminar) al inicio, pudieron completarlas tras la intervención. Estos importantes beneficios en tan poco tiempo (4 semanas) podrían estar relacionados con tres elementos clave: individualización del programa, frecuencia diaria y motivación del entrenamiento dirigido.

Palabras clave: ancianos, caídas, centros de cuidado, atención primaria

\section{RESUMO}

Neste estudo, foram determinados os efeitos de um programa individualizado de exercícios multicomponentes de quatro semanas (Vivifrail) sobre a fragilidade física e a incapacidade funcional em idosos residentes em casas de repouso. Quatorze indivíduos institucionalizados (idade 81,7 \pm 9,7 anos) se voluntariaram para completar 4 semanas do programa de exercícios individualizado Vivifrail (5 dias por semana), de acordo com seu nível inicial: A, incapacidade; B, fragilidade; C, pré-fragilidade e D, robusto. Os treinamentos foram conduzidos por educadores físicos e esportivos certificados. Onze participantes completaram as 4 semanas com níveis muito altos de participação (96\%). A capacidade funcional (escore SPPB) melhorou em todos os participantes $(+48,2 \%, p<0,001)$ e testes: levantar da cadeira $(24,1 \%, p=0,003)$, velocidade de caminhada $4 \mathrm{~m}(9,8 \%, p=0,033)$ e $6 \mathrm{~m}(7,2 \%, p=0,017) \mathrm{e}$ teste Up and Go $(11,2 \%, p=0,004)$. Incapacidade e sarcopenia diminuíram significativamente (SARC-F, $p=0,026$; índice de Lawton, $p=0,013$ ). Pessoas que iniciaram com níveis de incapacidade (A), fragilidade (B) e pré-fragilidade (C) apresentaram melhores resultados. Seis dos nove participantes que iniciaram com a condição física ou préfragilidade $(66,7 \%)$ reverteram essa condição após a intervenção. Além disso, 33\% dos participantes que não conseguiram realizar os testes funcionais (sentar, levantar e andar) na linha de base, conseguiram concluí-los após a intervenção. Esses importantes benefícios em tão pouco tempo (4 semanas) podem estar relacionados a três elementos principais: individualização do programa, frequência diária e motivação do treinamento direcionado.

Palavras chave: anciãos, quedas, centros de atendimento, atenção primária

\section{INTRODUCCIÓN}

Frailty is a multicausal syndrome associated with the ageing process that causes a decrease in physical condition, functional capacities and physiological functions which leads to increments in disability, dependency and mortality (Morley et al., 2013). In Spain, the prevalence of frailty among people older than 75 years is 30\% (Santos-Eggimann et al., 2009). Among other complications, frail older adults suffer from weakness due to musculoskeletal disorders (e.g., sarcopenia) that increases polypharmacy and hospitalization, severely limits their daily activities and drastically reduce their quality of life (Cano et al., 2018; Cesari et al., 2016; Gutiérrez-Valencia et al., 2018).

There are increasing evidence that physical activity in older adults is a safe and efficient treatment to preserve functional and cognitive abilities while mitigating 


\section{Vivifrail exercise program in nursing homes}

metabolic complications associated with frailty (Courel-Ibáñez \& Pallarés, 2019; de Souto Barreto et al., 2016; Lopez et al., 2017; Valenzuela et al., 2019), to the extent that being considered mandatory in primary care (Izquierdo et al., 2016). In particular, multicomponent programmes combining strength, balance, stretching and cardiovascular exercises are shown to be more effective in maintaining mobility and musculoskeletal function among frailty older adults (Cadore et al., 2014; Tarazona-Santabalbina et al., 2016). The recently-created Vivifrail program constitutes one of the most promising multicomponent exercise programs for older people (Izquierdo, 2019; Izquierdo et al., 2017). The program is tailored to six specific conditions regarding the mobility limitation and the risk of falling. Furthermore, the Vivifrail App allows individuals' monitoring and provides clear instructions to effectively complete the program within the everyday environment.

Spain is the fourth country with the longest life expectancy in the world (WHO, 2016), decade with more than 270,000 persons living in nursing homes, being $49.8 \%$ over 80 years old (INE, 2013). The prevalence of frailty in people living in nursing homes in Spain is 68\% (O'Caoimh et al., 2018). This rise in the number of institutionalized older people must be accompanied by a parallel strengthening of health support and treatments for preventing sarcopenia and frailty (de Souto Barreto et al., 2016). Hence, the insertion of the Vivifrail multicomponent exercise among long-term exercise interventions in older adults is promising.

The aim of this study was to determine the effects of a 4-week multicomponent exercise program Vivifrail on physical frailty and functional disability in older adults living in nursing homes.

\section{METHODS}

\section{Study design}

This study is part of the HEAL study (Courel-Ibáñez \& Pallarés, 2019), an ongoing multicentre, randomized controlled trial (NCT03827499). One group of institutionalized older adults living in nursing homes completed four weeks of the Vivifrail multicomponent exercise training program (Izquierdo, 2019). Training sessions were tailored according to the Vivifrail classification. Functional capacity and disability were evaluated at the beginning (baseline) and after the 4-week exercise intervention. This is a multidisciplinary intervention involving two strength and conditioning trainers, one sport scientists, one physiotherapist, one doctor, two nurses and the centre managers.

\section{Participants and eligibility criteria}

Fourteen older adults (aged $81.7 \pm 9.7$ years; height $155.7 \pm 11.5 \mathrm{~cm}$; weight $71.4 \pm 23.0 \mathrm{~kg} ; 57 \%$ women and $43 \%$ men) were recruited from a nursing home that volunteered to participate in this study. All participants met the inclusion criteria according to the HEAL study protocol (Courel-Ibáñez \& Pallarés, 2019), were informed of the characteristics of the study and provided a signed consent. Enrolment of cognitively impaired older adults required proxy permission (family member or caregiver). All potential participants provided a medical history and undergo a medical examination to identify cardiovascular or metabolic conditions that would exclude participation. The study was conducted according to the Declaration of Helsinki and approved by the Ethics Commission of the local university.

\section{Multicomponent physical exercise intervention}

After the initial assessment, participants attended a familiarization week to be intrusted about their specific exercise routine. Participants completed 4 weeks of the Vivifrail program according to their initial level: A, disability; B, frailty; C, pre-frailty and $\mathrm{D}$, robust. People allocated in the A program and those with fall risk completed a 5-days-a-week routine of multicomponent exercises, while the rest combined strength, balance and stretching exercises (3 days a week) with walking (2 days a week). Training sessions were integrated as an external service of the nursing home and schedule with the rest of activities to ensure the compliance of participants. Sessions were performed in groups of seven people at the outdoor courtyard. The costs derived from the intervention were those generated by hiring two strength and conditioning trainers for a week and approximately $250 €$ in fitness equipment (dumbbells, steps, cones, ankle weights, and handgrip balls). The sessions were directed by qualified strength and conditioning trainers and supervised by the doctor, the physiotherapist, the nurses and the centre managers.

Outcome measures

A detailed explanation of each measurement was described elsewhere (Courel-Ibáñez \& Pallarés, 


\section{Buendía-Romero, Á., García-Conesa, S., Pallarés, J.G. \& Courel-Ibáñez, J.}

2019). The functional capacity (main outcome) was measured using the Short Physical Performance Battery (SPPB) test scores (from 1 to 12), depending on performance in i) gait speed (4 and 6 meters), ii) 5sit-to-stand test, iii) balance test and iv) time up and go. Isometric handgrip strength was evaluated with a digital dynamometer (TKK 5101, Grip-D, Takey, Tokio, Japan) to assess the maximal $(\mathrm{kg})$ and relative strength (kg/body mass). Disability was tested using the Barthel (0 to 100) and Lawton (0 to 8) indexes. SARC-F test (0 to 10$)$ was used to diagnose poor physical function and sarcopenia.

\section{Statistical analyses}

Standard statistical methods were used for the calculation of the mean and standard deviations (SD). Student's $t$-test was used to determine differences between pre and post intervention averages being significant level was set $p<0.05$. The effect size was estimated with Hedge $g$ for reduced samples and interpreted as large $(g>0.80)$ moderate $(g>0.50)$ and small $(g>0.20)$ effect. All calculations were done with a spreadsheet Microsoft Excel 2016 and the statistical software SPSS version 22 (IBM Corp., Armonk, NY, USA).

\section{RESULTS}

Eleven participants completed the pre and post evaluations (78.6\% compliance) with very high levels of attendance (96\% of the training sessions) for a total of 18 training sessions. Changes in functional capacity and disability are shown in Table 1 . There were significant increments in the SPPB test scores $(+48.2 \%, p<0.001)$, Sit-to-Stand $(24.1 \%$ faster, $p=$ $0.003)$, gait speed $4 \mathrm{~m}(9.8 \%$ faster, $p=0.033)$ and 6 $\mathrm{m}(7.2 \%$ faster, $p=0.017)$ and Up-and-Go $(11.2 \%$ faster, $p=0.004)$, and reductions in SARC-F ( $p=$ $0.026)$ and Lawton index $(p=0.013)$. Barthel index and handgrip strength improved, but not reaching statistical significance.

Comparisons between the different programmes revealed that the greatest improvements were shown in the population with higher levels of disability (A), frailty (B) and pre-fragility (C). Six of the nine participants who started with physical frailty or prefrailty status $(66.7 \%)$ reversed this condition after the intervention. None of the participants deteriorated his/her physical performance in any of the tests. In addition, $33 \%$ of the participants with disability, who were unable to perform the mobility tests (i.e., up and go, sit-to-stand and gait speed), became able to complete them after the intervention.

Table 1. Functional capacity and disability before (baseline) and after (after 4 weeks) the VIVIFRAIL exercise intervention.

\begin{tabular}{|c|c|c|c|c|}
\hline \multirow{2}{*}{ Parameters } & Baseline & After 4 weeks & \multirow{2}{*}{$p$} & \multirow{2}{*}{ ES } \\
\hline & $\mathrm{M}(\mathrm{SD})$ & $\mathrm{M}(\mathrm{SD})$ & & \\
\hline \multicolumn{5}{|l|}{ Functional capacity } \\
\hline SPPB (points) & $4.3(3.5)$ & $7.1(3.9)$ & $<0.001 *$ & 0.71 \\
\hline Up and Go (s)a & $20.3(11.1)$ & $16.1(11.9)$ & $0.004 *$ & 0.33 \\
\hline Sit-to-Stand (s)a & $17.2(3.9)$ & $10.8(1.6)$ & $0.003^{*}$ & 2.01 \\
\hline Gait speed $4 \mathrm{~m}(\mathrm{~s})_{\mathrm{a}}$ & $7.9(3.5)$ & $6.5(3.7)$ & $0.033^{*}$ & 0.37 \\
\hline Gait speed $6 \mathrm{~m}(\mathrm{~s})_{\mathrm{a}}$ & $12.2(5.1)$ & $10.1(5.2)$ & $0.017 *$ & 0.40 \\
\hline \multicolumn{5}{|l|}{ Handgrip strength } \\
\hline D. hand (kg) & $21.0(9.2)$ & $22.0(8.9)$ & 0.297 & 0.11 \\
\hline D. hand (kg/bm) & $0.27(0.10)$ & $0.29(0.08)$ & 0.287 & 0.16 \\
\hline N.D. hand (kg) & $19.7(8.5)$ & $20.6(7.2)$ & 0.255 & 0.11 \\
\hline N.D. hand (kg/bm) & $0.25(0.09)$ & $0.27(0.08)$ & 0.171 & 0.14 \\
\hline \multicolumn{5}{|l|}{ Disability } \\
\hline Index Barthel (points) & $76.3(21.4)$ & $82.1(17.5)$ & 0.198 & 0.29 \\
\hline Index Lawton (points) & $3.3(2.2)$ & $5.4(1.8)$ & $0.013 *$ & 0.99 \\
\hline \multicolumn{5}{|l|}{ Sarcopenia } \\
\hline SARC-F (points) & $3.7(2.5)$ & $2.2(2.4)$ & $0.026^{*}$ & 0.59 \\
\hline
\end{tabular}

\section{DISCUSSION}

The results of this study demonstrate that face-to-face, daily short interventions (18 training sessions, 5 days a week), tailored multicomponent exercise program (Vivifrail) produces important functional and mobility improvement in octogenarian people living in nursing homes. In particular, $70 \%$ of participants who started with physical frailty symptoms reversed this condition after 4 weeks of exercise training. These findings confirmed those previously reported about the benefits of the Vivifrail program in acutely hospitalized older adults (Sáez de Asteasu et al., 2020) and urge to include it as an accessible, safe and effective physical activity among nursing homes.

The current improvements obtained in physical capacities and mobility are consistent with previous similar interventions longer in duration of 6 weeks or more (Martínez-Velilla et al., 2019; Tarazona- 


\section{Vivifrail exercise program in nursing homes}

Santabalbina et al., 2016) and superior to those obtained with a twice-a-week training frequency (García-Molina et al., 2018) and others with homebased training programs not directed in person (Fairhall et al., 2014). Hence, the greater benefits found in such a shorter period of time (4 weeks) could be related to three key elements: individualization of the program, daily frequency (Izquierdo, 2019) and face-to-face coaching motivation by physical conditioning professionals (Yan et al., 2011). This last emphasized the importance of including strength and conditioning professionals within the staff in nursing homes and long-term care centers to maximize the adherence and benefits of the exercise programs in older adults.

Physical progresses should be analysed with special attention to the initial level of the person. Our findings suggest that the Vivifrail program would be particularly efficient in people with frailty or prefrailty status compared to those that are in a robust condition. This notion is support by previous multicomponent interventions who found smaller physical improvements on participants whit higher initial levels (SPPB > 8.5) than ours (TarazonaSantabalbina et al., 2016). Likewise, a recent study on 300 acute care for elders unit found greater changes in muscle power after 5 to 7 consecutive days of Vivifrail ( 2 sessions a day) compared to the usual care program (Sáez de Asteasu et al., 2020). Considering the high prevalence of physical frailty and comorbidities among nursing home residents in Spain (O'Caoimh et al., 2018), it seems pertinent to ensure a proper multicomponent exercise program as a main daily activity as a complement to usual physiotherapies to maintain older people's functional capacity and mitigate musculoskeletal disorders associated with aging.

A main contribution of the present study is that $33 \%$ of people with disability (SPPB $<3$ points) or limited mobility (SPPB $<6$ points) reversed this condition and became able to complete daily mobility tasks (sit and stand from a chair and walk a few meters) that one week before were impossible for them. Whereas previous interventions have shown an increase in functionality and walking speed in people with reduced mobility (Freiberger et al., 2012; GarcíaMolina et al., 2018), this seems to be the first time reporting these kinds of improvements in people with a disability or reduced mobility. This seems particularly important given that people with reduced or no mobility are in risk of muscle waste due to immobilization that eventually lead to a disuseinduced atrophy (Bodine, 2013). In this sense, according to recent reviews (Courel-Ibáñez et al., 2019; Travers et al., 2019), it is recommended the combination of oral nutritional supplementation in addition to exercise to maximize the strength and muscle gains and accelerate mobility recovery in frail people.

As a main limitation, it is remarkable that handgrip strength was the only physical tests that did not reach a significant change, which may be a consequence of the inadequate intensity and volume in upper body exercises (Richardson et al., 2019) or because of the short duration of the intervention. Furthermore, it must be acknowledged that these are partial results from an ongoing randomized control trial (Courel-Ibáñez \& Pallarés, 2019). As a main strength, it is remarkable the multidisciplinary approach (including physical conditioning trainers, physiotherapists, sport scientists, doctors, nurses and managers) and the positive adoption of the intervention among participants and their relatives. At the time of writing, the participants of this study are maintaining their daily physical training as a service of the nursing home.

\section{CONCLUSIONS}

A daily, low-cost, face-to-face intervention of the individualized multicomponent exercise program Vivifrail has been shown to improve functional capacity and reverse physical frailty in a short period of time in octogenarian people living in nursing homes.

\section{ACKNOWLEDGEMENTS}

We thank the strength and conditioning trainers, medical doctors, nurses, and physical therapists involved in the intervention in and to all the patients that have participated in the study. All authors contributed equally in the present study as well as in the preparation of manuscript. All authors read and approved the final manuscript. 


\section{Buendía-Romero, Á., García-Conesa, S., Pallarés, J.G. \& Courel-Ibáñez, J.}

\section{CONFLICT OF INTEREST}

The authors declare no conflicts of interest

\section{FUNDING:}

This study was funded by the Autonomous Community of the Region of Murcia, Regional Program for the Promotion of Scientific and Technical Research (Action Plan 2018), Seneca FoundationAgency of Science and Technology, Region of Murcia (ID: 20872/PI/18).

\section{REFERENCES}

1. Bodine, S. C. (2013). Disuse-induced muscle wasting. The International Journal of Biochemistry \& Cell Biology, 45(10), 2200-2208. https://doi.org/10.1016/j.biocel.2013.06.011

2. Cadore, E. L., Casas-Herrero, A., ZambomFerraresi, F., Idoate, F., Millor, N., Gómez, M., Rodriguez-Mañas, L., \& Izquierdo, M. (2014). Multicomponent exercises including muscle power training enhance muscle mass, power output, and functional outcomes in institutionalized frail nonagenarians. Age, 36(2), 773-785. https://doi.org/10.1007/s11357-0139586-Z

3. Cano, A., Dargent, G., Carriazo, A., LópezSamaniego, L., Apostolo, J., Campos, E., Holland, C., Varela-Nieto, I., Luz Sánchez-Sánchez, M., Illario, M., Iaccarino, G., Roller, R. E., Goossens, E., Vollenbroek-Hutten, M., Pais, S., Schena, F., Musian, D., Alvino, S., Maggio, M., ... Obbia, P. (2018). Tackling frailty and functional decline: Background of the action group A3 of the European innovation partnership for active and healthy ageing. Maturitas, 115, 69-73. https://doi.org/10.1016/j.maturitas.2018.06.009

4. Cesari, M., Prince, M., Thiyagarajan, J. A., De Carvalho, I. A., Bernabei, R., Chan, P., GutierrezRobledo, L. M., Michel, J.-P., Morley, J. E., Ong, P., Rodriguez Manas, L., Sinclair, A., Won, C. W., Beard, J., \& Vellas, B. (2016). Frailty: An Emerging Public Health Priority. Journal of the American Medical Directors Association, 17(3), 188-192. https://doi.org/10.1016/j.jamda.2015.12.016
5. Courel-Ibáñez, J., \& Pallarés, J. G. (2019). Effects of $\beta$-hydroxy- $\beta$-methylbutyrate (HMB) supplementation in addition to multicomponent exercise in adults older than 70 years living in nursing homes, a cluster randomized placebocontrolled trial: the HEAL study protocol. $B M C$ Geriatrics, 19(1), 188. https://doi.org/10.1186/s12877-019-1200-5

6. Courel-Ibáñez, Vetrovsky, Dadova, Pallarés, \& Steffl. (2019). Health Benefits of $\beta$-Hydroxy- $\beta$ Methylbutyrate (HMB) Supplementation in Addition to Physical Exercise in Older Adults: A Systematic Review with Meta-Analysis.

Nutrients, 11(9), 2082. https://doi.org/10.3390/nu11092082

7. de Souto Barreto, P., Morley, J. E., ChodzkoZajko, W., H. Pitkala, K., Weening-Djiksterhuis, E., Rodriguez-Mañas, L., Barbagallo, M., Rosendahl, E., Sinclair, A., Landi, F., Izquierdo, M., Vellas, B., \& Rolland, Y. (2016).

Recommendations on Physical Activity and Exercise for Older Adults Living in Long-Term Care Facilities: A Taskforce Report. Journal of the American Medical Directors Association, 17(5), 381-392. https://doi.org/10.1016/J.JAMDA.2016.01.021

8. Fairhall, N., Sherrington, C., Lord, S. R., Kurrle, S. E., Langron, C., Lockwood, K., Monaghan, N., Aggar, C., \& Cameron, I. D. (2014). Effect of a multifactorial, interdisciplinary intervention on risk factors for falls and fall rate in frail older people: A randomised controlled trial. Age and Ageing, 43(5), 616-622. https://doi.org/10.1093/ageing/aft204

9. Freiberger, E., Häberle, L., Spirduso, W. W., \& Rixt Zijlstra, G. A. (2012). Long-term effects of three multicomponent exercise interventions on physical performance and fall-related psychological outcomes in community-dwelling older adults: a randomized controlled trial. Journal of the American Geriatrics Society, 60(3), 437-446.

10. García-Molina, R., Ruíz-Grao, M. C., NoguerónGarcía, A., Martínez-Reig, M., Esbrí-Víctor, M., Izquierdo, M., \& Abizanda, P. (2018). Benefits of 


\section{Vivifrail exercise program in nursing homes}

a multicomponent Falls Unit-based exercise program in older adults with falls in real life. Experimental Gerontology, 110, 79-85. https://doi.org/10.1016/j.exger.2018.05.013

11. Gutiérrez-Valencia, M., Izquierdo, M., LacalleFabo, E., Marín-Epelde, I., Ramón-Espinoza, M. F., Domene-Domene, T., Casas-Herrero, Á., Galbete, A., \& Martínez-Velilla, N. (2018). Relationship between frailty, polypharmacy, and underprescription in older adults living in nursing homes. European Journal of Clinical Pharmacology, 74(7), 961-970. https://doi.org/10.1007/s00228-018-2452-2

12. INE. (2013). Población residente en establecimientos colectivos.

13. Izquierdo, M. (2019). Multicomponent physical exercise program: Vivifrail. Nutricion

Hospitalaria, 36(Ext2), 50-56. https://doi.org/10.20960/nh.02680

14. Izquierdo, M., Casas-Herrero, A., ZambmFerraresi, F., Martínez-Velilla, N., AlonsoBouzón, C., Rodríguez-Mañas, L., \& VIVIFRAIL. (2017). A Practical Guide for Prescribing a Multi-Component Physical Training Program to prevent weakness and falls in People over 70.

http://www.vivifrail.com/resources/send/3documents/21-guide

15. Izquierdo, M., Rodriguez-Mañas, L., CasasHerrero, A., Martinez-Velilla, N., Cadore, E. L., \& Sinclair, A. J. (2016). Is It Ethical Not to Precribe Physical Activity for the Elderly Frail? Journal of the American Medical Directors Association, 17(9), 779-781. https://doi.org/10.1016/j.jamda.2016.06.015

16. Lopez, P., Izquierdo, M., Radaelli, R., Shurzzi, G., Grazioli, R., Pinto, R. S., \& Cadore, E. L. (2017). Effectiveness of Multimodal Training on Functional Capacity in Frail Older People: A Meta-Analysis of Randomized Controls Trials. Journal of Aging and Physical Activity, 1-36. https://doi.org/10.1123/japa.2017-0188

17. Martínez-Velilla, N., Casas-Herrero, A.,
Zambom-Ferraresi, F., Sáez de Asteasu, M. L., Lucia, A., Galbete, A., García-Baztán, A., Alonso-Renedo, J., González-Glaría, B., GonzaloLázaro, M., Apezteguía Iráizoz, I., GutiérrezValencia, M., Rodríguez-Mañas, L., \& Izquierdo, M. (2019). Effect of Exercise Intervention on Functional Decline in Very Elderly Patients During Acute Hospitalization. JAMA Internal Medicine, 179(1), 28. https://doi.org/10.1001/jamainternmed.2018.4869

18. Morley, J. E., Vellas, B., van Kan, G. A., Anker, S. D., Bauer, J. M., Bernabei, R., Cesari, M., Chumlea, W. C., Doehner, W., Evans, J., Fried, L. P., Guralnik, J. M., Katz, P. R., Malmstrom, T. K., McCarter, R. J., Gutierrez Robledo, L. M., Rockwood, K., von Haehling, S., Vandewoude, M. F., \& Walston, J. (2013). Frailty consensus: a call to action. Journal of the American Medical Directors Association, 14(6), 392-397. https://doi.org/10.1016/j.jamda.2013.03.022

19. O’Caoimh, R., Galluzzo, L., Rodríguez-Laso, Á., Van der Heyden, J., Ranhoff, A. H., LampriniKoula, M., Ciutan, M., López-Samaniego, L., Carcaillon-Bentata, L., Kennelly, S., Liew, A., \& Work Package 5 of the Joint Action ADVANTAGE. (2018). Prevalence of frailty at population level in European ADVANTAGE Joint Action Member States: a systematic review and meta-analysis. Annali Dell'Istituto Superiore Di Sanita, 54(3), 226-238.

https://doi.org/10.4415/ANN_18_03_10

20. Richardson, D. L., Duncan, M. J., Jimenez, A., Juris, P. M., \& Clarke, N. D. (2019). Effects of movement velocity and training frequency of resistance exercise on functional performance in older adults: a randomised controlled trial. European Journal of Sport Science, 19(2), 234246.

21. Sáez de Asteasu, M. L., Martínez-Velilla, N., Zambom-Ferraresi, F., Ramírez-Vélez, R., GarcíaHermoso, A., Cadore, E. L., Casas-Herrero, Á., Galbete, A., \& Izquierdo, M. (2020). Changes in muscle power after usual care or early structured exercise intervention in acutely hospitalized older adults. Journal of Cachexia, Sarcopenia and Muscle, jcsm.12564. 


\section{Buendía-Romero, Á., García-Conesa, S., Pallarés, J.G. \& Courel-Ibáñez, J.}

https://doi.org/10.1002/jcsm.12564

22. Santos-Eggimann, B., Cuenoud, P., Spagnoli, J., \& Junod, J. (2009). Prevalence of Frailty in Middle-Aged and Older Community-Dwelling Europeans Living in 10 Countries. The Journals of Gerontology Series A: Biological Sciences and Medical Sciences, 64A(6), 675-681. https://doi.org/10.1093/gerona/glp012

23. Tarazona-Santabalbina, F. J., Gómez-Cabrera, M. C., Pérez-Ros, P., Martínez-Arnau, F. M., Cabo, H., Tsaparas, K., Salvador-Pascual, A., Rodriguez-Mañas, L., \& Viña, J. (2016). A Multicomponent Exercise Intervention that Reverses Frailty and Improves Cognition, Emotion, and Social Networking in the Community-Dwelling Frail Elderly: A Randomized Clinical Trial. Journal of the American Medical Directors Association, 17(5), 426-433. https://doi.org/10.1016/j.jamda.2016.01.019

24. Travers, J., Romero-Ortuno, R., Bailey, J., \& Cooney, M. T. (2019). Delaying and reversing frailty: a systematic review of primary care interventions. British Journal of General Practice, 69(678), e61-e69. https://doi.org/10.3399/bjgp18X700241

25. Valenzuela, P. L., Castillo-García, A., Morales, J. S., Izquierdo, M., Serra-Rexach, J. A., SantosLozano, A., \& Lucia, A. (2019). Physical exercise in the oldest old. Comprehensive Physiology, 9(4), 1281-1304. https://doi.org/10.1002/cphy.c190002

26. WHO. (2016). World Health Statistics 2016: Monitoring health for the SDGs.

27. Yan, T., Wilber, K. H., \& Simmons, W. J. (2011). Motivating high-risk older adults to exercise: Does coaching matter? Home Health Care Services Quarterly, 30(2), 84-95. https://doi.org/10.1080/01621424.2011.569670 